\title{
АНРІ ЛАНГЛУА І ФРАНЦУЗЬКА СІНЕМАТЕКА
}

Статтю присвячено діяльності світових кіноархівів, зокрема одного з найбільших і найавторитетніших із них - Франиузької сінематеки. Розглядається також внесок у кіноархівну справу засновника і багаторічного директора Сінематеки - Анрі Ланглуа, щяо перетворив цеей заклад в один із иентрів просвітнииької діяльності і кіноосвіти, збагативши його фільмами багатьох краӥн світу $i$ запропонувавщи новий системний підхід до збереження фільмів.

Ключові слова: Сінематека, Анрі Ланглуа, кіноархівна справа, просвітницво.

Статья посвящена деятельности мировых киноархивов, а именно Франиузской синематеке - одной из наибольших и наиболее авторитетной из них. Также рассматривается вклад в киноархивное дело основателя и многолетнего директора Синематеки - Анри Ланглуа, который превратил это учреждение в один из иентров просветительской деятельности и кинообразования, обогатив его фильмами из многих стран мира и предложив свой системный подход к сохранению фильмов.

Ключевые слова: Синематека, Анри Ланглуа, киноархивное дело, просвещение.

The article is dedicated to the activities of the world cinema archives, in particular to the French Cinemateque, and its founder Henri Langlois. Under his directorship, Cinemateque became one of the most important centres of the cinema education. Langlois enriched it with films coming from diverse countries, and offered a systematic approach to the preservation of films.

Keywords: French Cinemateque, Henri Langlois, cinema arkhiv work, enlightenment.

Кінематограф увійшов у світову культуру як недорога ярмаркова розвага, тому сама ідея зберігання фільмів виникла через кілька десятиліть після перших кіносеансів.

Таке ставлення до екранних творів призвело до значних втрат, що їх немає можливості відшкодувати. Зокрема, це стосується українського кінематографа - майже весь масив дореволюційного періоду виявився назавжди втраченим. Сучасні архівісти, які працюють в галузі кіно, повинні докласти максимум зусиль, аби не лише зберегти наявний кінофонд, а спрямувати всі сили на відшукання того, що вважалось загубленим. Такі щасливі випадки є. Завдяки зусиллям французького кінознавця українського походження Любомира Госейка було виявлено, що під назвою «Запорожці» у Французькій сінематеці зберігається фільм П. Чардиніна «Тарас Трясило» 3 А. Бучмою в головній ролі. 3 Німеччини було одержано частину фільму Г. Тасіна «Джиммі Гіггінс», де знов-таки А. Бучма зіграв одну з найкращих своїх ролей, а також незавершений фільм О. Довженка «Проща- вай, Америко!» - 3 «Белых Столбов» Держфільмофонду Росії.

Хочеться сподіватися, що в надрах зарубіжних фільмотек буде знайдено знищений свого часу фільм І. Кавалерідзе «Злива». Це, можна сказати, один з унікальних прикладів у світовому кіно, коли кінематографіст відверто вдається в своєму екранному рішенні до стилістики кубізму.

Свого часу було загублено чимало стрічок таких видатних кіномитців, які стояли біля колиски кіномистецтва, як Жорж Мельєс, Макс Ліндер, Бастер Кітон. Лише через десятиліття, завдяки зусиллям ентузіастів, їхні фільми почали повертатися в кінообіг. Відомо, що після краху фірми Мельєса залишилося зовсім небагато картин цього видатного митця. А сам він доживав свої дні у Будинку-притулку для майстрів мистецтва Франції. Але зусиллями його праправнучки реставровано усі знайдені його фільми. Причому їм було повернуто колір, адже відомо, що фільми Мельєса в його студії в Монтреї розфарбовувались від руки. Сьогодні програму фільмів Мельєса показують у 
різних країнах світу. Побувала вона і в Києві під час фестивалю «Молодість», i, оскільки демонстрація велася на великому екрані, в супроводі живої музики, «тапером» виступив праправнук Мельєса. Глядачі могли переконатися, що «архівні плівки» Мельєса і сьогодні не втратили своєї мистецької цінності і вражають польотом фантазії та оригінальністю зображального рішення.

Можна зрозуміти, чому одним 3 перших найбільших кінематографічних вражень ще в дитинстві для великого режисера Сергія Ейзенштейна стали саме фільми Мельєса.

Не менш цінним було повернення стрічок Макса Ліндера, які, здавалося б, канули в небуття. Зусиллями його дочки Мод Ліндер було розшукано у різних країнах світу стрічки або фрагменти ix, що збереглися. Мод Ліндер змогла змонтувати репрезентативний фільм, в якому представлено різні роботи великого комедіографа, починаючи 3 його перших невибагливих «комічних» до таких зрілих шедеврів, як «Сім років нещастя» і «Три пройдисвіти» (комедійна інтерпретація «Трьох мушкетерів» О. Дюма).

Більше пощастило фільмам Чарлі Чапліна. Увагу шанувальників кіно привернув фільм «Невідомий Чаплін», змонтований з обрізків плівки, що ix великий митець викинув до кошика. Чаплін, як справжній перфекціоніст, залишав у останньому варіанті фільму лише найвиразніші й найнеобхідніші для передачі змісту кадри та епізоди, нехтуючи навіть тими, що самі по собі були маленькими шедеврами. Так, завдяки цим «архівним» плівкам склалося більш повне враження про методи роботи Чапліна і його творчий митецький потенціал.

На жаль, у Радянському Союзі фільми зникали не лише через нерозуміння цінності того чи іншого твору. Вони просто інколи знищувались цілеспрямовано. По-перше, вважалося значною економією добувати 3 плівки срібло або змивати фільми, щоб повторно використати іiі. Найпершими жертвами стали стрічки, зняті до Жовтневого перевороту. Ставлення до них дуже яскраво виявилося в сценарії, що належав перу братів Васильєвих, майбутніх авторів знаменитого «Чапаєва». Там ішлося про механіка-«ретрограда», який обожнює Віру Холодну і збирає всі ії фільми. Але 3 ним проводять «виховну» роботу комсомольці й переконують у тому, що творчість цієї актриси не становить ніякої цінності, а $є$ відображенням занепадницького світу минулого. Механік «прозріває» і здає плівку з фільмами Холодної в утиль, зауважуючи при цьому, що хоч якась користь 3 неї буде, хай піде краще на гребінці.
Сумна доля чекала на фільми, зняті в дореволюційні часи в Україні, їх майже не збереглося.

I таких прикладів чимало. Тому таким важливим $\epsilon$ процес утворення кіносховищ-фільмотек, в яких фільми мають не лише зберігатися, а й бути доступними для переглядів як фахівцями, так i звичайними глядачами.

У світі $є$ низка кіноархівів, які стали центрами наукової інформації і пропаганди кіномистецтва. Саме такий архів $\epsilon$ складовою частиною Британського інституту кінематографії (BFI), заснований у 1933 році. Відділ інформації і документації інституту має величезну картотеку і бібліотеку - понад двадцять тисяч книг; редакційно-видавничий відділ випускає щоквартальник «Sight\&Sound» ${ }^{1}$, а також різноманітні каталоги i книги по кіно. Також Інститут підтримує зв'язок 3 асоціаціями любителів кіно, та особливе значення має фінансова підтримка режисерів-початківців. Зокрема Гріневей ${ }^{2}$ поставив свій перший фільм саме завдяки фінансуванню Інституту.

Розшук загублених кінострічок провадять усі кіноархіви світу. Найбільш послідовно і постійно це робить Британський кіноінститут (BFI). Наприклад, складено список з 75 фільмів, які вважаються втраченими. Співробітники інституту плекають надію, що люди, які щиро залюблені в кінематограф і у яких могли зберегтися ці дорогоцінні плівки, відгукнуться і деякі з цих фільмів буде знайдено. Цей список очолює другий фільм Гічкока - «Гірський орел», знятий у 1926 році, режисерський дебют Майкла Пауела, а також фільм «Лінда» 1960 року, молодіжна драма, жанр, який став популярним у руслі творчості «молодих розгніваних» ${ }^{3}$, та інші.

Світові архіви не лише ведуть пошукову роботу, а й активно пропагують свої надбання. Так, Американський інститут кіномистецтва (AFI) запустив новий портал, де подаються сотні відеороликів $з$ його архіву. Треба сказати, що за сорок два роки існування інституту накопичилось близько 10 годин відеоматеріалів, які раніше були незнайомі широкій публіці. Великий кіноархів має і Американська академія кінематографічних мистецтв і наук, котра щорічно, починаючи з 1929 року, присуджує премію за найкращий фільм, яка 3 часом отримала назву «Оскар».

Одним 3 таких найбільших і найстаріших фільмосховищ $\epsilon$ Французька сінематека.

Хто ж стояв біля витоків Французької сінематеки?

Тут слід назвати французького режисера Жоржа Франжю. В творчості Франжю знаходять 
своє виразне втілення такі протилежні напрями, як поетичний реалізм і сюрреалізм. Естетика його фільмів часто здавалася критикам контраверсійною, бо він поєднував відвертий показ насильства зі зворушливим ліризмом. Його захоплювали найрізноманітніші жанри, так широку відомість йому приніс фільм «Жюдекс», який був свого роду рімейком знаменитого серіалу Фейада ${ }^{4}$. Iнколи він звертався до авторів, які були абсолютно протилежні за своєю стилістикою. В 1962 році він екранізує роман Ф. Моріака «Тереза Декейру», а в 1965-му — твір Жана Кокто «Самозванець Тома». Далі звертається до Е.Золя - «Помилка аббата Мюре» (1970). Слід зауважити, що починав він як документаліст, найбільш помітними були такі його фільми, як «Кров тварин» (1949), «Дім Інвалідів» (1952), біографічні фільми - «Великий Мельєс», «Пан і пані Кюрі», а також «Національний народний театр» (1956). 3 кінця 1950-х він працює в одному напрямі з іншими митцями «нової хвилі», в естетику якої вписуються його стрічки «Головою об стінку» (1959), «Очі без обличчя» (1960) і «Весь вогонь на вбивцю» (1961). Ці фільми були неоднозначно зустрінуті критикою, проте сьогодні зрозуміло, що мистецький вплив Франжю на процеси в французькому кіномистецтві був вагомим.

Та нас понад усе цікавить початок його роботи в кінематографі, а він пов'язаний, передусім, саме з активною популяризацією тих творів французького кіно, які вже, здається, належали лише iсторіï.

У 1935 році він разом з Анрі Ланглуа створює гурток кінолюбителів. А в 1936 стає одним з фундаторів Французької сінематеки, де працює до 1938 року. Згодом - обіймає дуже важливу посаду виконавчого секретаря Міжнародної федерації кіноархівів (FIAF). 3 1945-го по 1953 роки він починає працювати в системі наукового кіно і стає секретарем Інституту наукової кінематографії, що його очолював відомий майстер наукового кіно Жан Пенльове. Тоді ж він долучається і до роботи в документальному кіно, в якому посяде визначне місце.

Серед засновників Французької сінематеки не можна не згадати Жана Мітрі. Його називали «живою пам'яттю кінематографа». Вже 31924 року він активно працював у кіноклубах, був дописувачем авангардних часописів. В 1928 році брав активну участь у зйомках фільму «Париж-Сінема» П'єра Шеналя, в якому йдеться про прихований від очей глядача зворотний бік кінематографа. Пробував він себе і як актор, знявшись у 1932 році у фільмі «Ніч на перехресті» Жана Ренуара. Та найважливішою подією в його творчій біографії стала участь, разом з Франжю і Ланглуа, у створенні Французької сінематеки. Продовжуючи свої експериментальні спроби в галузі кінопрактики, він разом $з$ тим розкриває свій творчий потенціал як історик і теоретик кіно. За 20 років вийшло сім томів його «Історії кіно», яку критики вважали більш філософськи витриманою, ніж скажімо, праця Садуля. Хоч зауважували авторові й певний суб'єктивізм.

Другим досягненням Мітрі, яке ще більш працює на збереження «пам'яті кінематографа», стала його всесвітня фільмографія, яка складається 3 30-ти томів. Ця багатогранна особистість $\epsilon$ автором монографій про Гріффіта, Чапліна, Ейзенштейна, і майже всі останні роки він передавав свої знання студентам ІДЕКу і Паризького університету.

Та центральною постаттю серед засновників Французької сінематеки все ж став Анрі Ланглуа. Не бувши професійним кінокритиком чи істориком він, однак, відіграв значну роль не лише у французькому, а й у світовому кінопроцесі.

Все почалося в 1935 році, коли Анрі Ланглуа i його друг, майбутній відомий режисер Жорж Франжю, вирішили створити кіноклуб для показу німих фільмів. Скромно назвавши його «Кіногурток», вони показали на першому сеансі три колись знамениті німі стрічки: «Кабінет доктора Калігаpi», «Воля до смерті» і «Падіння дому Ашерів». Демонстрація цих шедеврів мала приголомшливий успіх. Так почала складатися знаменита концепція фільмотеки.

Для Ланглуа велике значення мало залучення до показу фільмів відомих кіномитців, навіть тих, чиє ім'я вже, здавалось би, стерлось 3 пам'яті глядачів. Так було організовано вечір Жоржа Мельєса, що мешкав тоді в замку Орлі, де містився притулок для літніх кінематографістів. I зачинатель світового кіно, незважаючи на свій похилий вік, охоче погодився зустрітися 3 членами кіноклубу і представити свій фільм «Подорож на Місяць».

Великим успіхом кіногуртка молодих сінефілів стало отримання в дар від відомого продюсера А. Каменки фільмів його студії. Це були як стрічки французьких авангардистів Ж. Епштейна, Р. Клера, М. Л’Ербьє, так і фільми російських режисерів, зняті на еміграції в Парижі.

Згодом мерія Парижа передає молодим ентузіастам великий покинутий будинок, де вони облаштовують і переглядовий зал, і фільмосховище. Перед сеансами проводили лекції, після - обго- 
ворення фільмів. Ланглуа був у захваті від того, що «нарешті народився репертуарний кінозал, про який стали багато говорити, і важко передати ту майже релігійну атмосферу, яка в ньому панувала» $[1,117]$.

1939 рік став роком офіційного заснування Французької сінематеки. Анрі Ланглуа, котра, за висловом Ж. Кокто, «стає драконом, що оберігає наші скарби».

Ланглуа не лише оберігав кіноскарби, а й активно їх поповнював. Характер цієї діяльності часто набував майже детективного забарвлення: йому вдалося врятувати копії фільмів німецького режисера Ганса Ріхтера, котрі він вивіз через дипломатичні канали з нацистської Німеччини, а в Парижі врятував американські фільми, які вже було підготовлено німцями до вивезення в Німеччину.

Під час багатолітньої роботи склалися найважливіші принципи і цінності, якими керувався Ланглуа. Він вважав, що в кожній країні має зберігатися якнайбільша кількість вітчизняних фільмів. Ланглуа доклав максимальних зусиль, аби повернути в Японію фільми, які під час війни були вивезені до Америки.

Ланглуа вважав, що в Сінематеці мають зберігатися всі відзняті в різний час фільми. Адже 3 часом стрічки, що здавалися сучасникам невдалими, могли бути переоціненими наступними поколіннями.

Вміння вибудовувати програму вражало глядачів сінематечних переглядів. Ставивши один фільм поруч з іншим, наприклад, стрічку А.Гічкока ${ }^{5}$ і стрічку К. Дреєра ${ }^{6}$, Ланглуа наче примушував глядача розкривати нові, невідомі ще грані їх таланту. Так сталося і з Гічкоком, в якому молоді глядачі Сінематеки побачили не лише вправного режисера трилерів, а й митця, що блискуче володіє кінематографічною формою.

Просвітницька місія Сінематеки була надзвичайно важливою. В їі роботі активну участь брали не лише визнані інтелектуали, такі, як Рене Клер ${ }^{7}$, Жан Кокто ${ }^{8}$, Жан-Поль Сартр ${ }^{9}$, а й молоді кінематографісти - Клод Шаброль ${ }^{10}$, Жан-Люк Годар ${ }^{11}$, Франсуа Трюффо ${ }^{12}$. Вони називали себе «дітьми Сінематеки», вважали, що цей заклад став для них справжнім університетом, де вони отримали свою кіноосвіту. Завдяки знайомству з кінокласикою молоді критики скоро самі стали до камери як режисери.Так відбулось народження французької «нової хвилі».

Для нас $є$ надзвичайно важливими свідчення одного $з$ найвидатніших представників «нової хвилі» Франсуа Трюффо. На все життя він зберіг враження від маленького залу на п'ятдесят місць на вулиці Мессін, де проводилися перегляди Сiнематеки. Цей будинок став місцем постійних зустрічей молодих французьких кінематографістів, де Трюффо познайомився з Жаком Ріветтом ${ }^{13}$, Жаном Люком Годаром та іншими митцями «нової хвилі». 3 почуттям гумору Трюффо згадує, як молоді кінематографісти, не маючи грошей на придбання квитків на всі сеанси, намагалися потайки залишитися в залі, щоб дивитися наступний фільм. I, попри пізне закінчення сеансів, «фанати» фільмотеки засиджувались там аж до зачинення метро, тож додому їм доводилося йти пішки. Серед відомих кінематографістів на Трюффо величезне враження справили історик німецького кіно Лотте Айснер ${ }^{14}$, а також зірка німого кіно Мюзідора ${ }^{15}$. I все ж головною постаттю був Анрі Ланглуа. Ось як його характеризує Трюффо: «Сам засновник Французької сінематеки був людиною блискучою, водночас простою і екстравагантною, охопленою однією ідеєю.

Як усі “маніяки”, Анрі Ланглуа поділяв світ людей і події на дві категорії: корисне для Сінематеки і шкідливе. Навіть якщо ви були знайомі 3 ним 10 років, він не витрачав часу на розмови про ваше здоров'я або сімейне життя, бо всі ці поняття пов' язувались для нього виключно 3 життєздатністю Сінематеки або ж сінематечної сім'ї. Він міг по-справжньому тепло ставитись до вас, якщо вам вдавалося на ходу підключитися до розмови 3 ним, точніше до його монологу на одну тему про змову, обставини якої могли бути вам невідомі, але це його абсолютно не бентежило» $[3,21]$.

Коли в 1968 році французький уряд спробував звільнити Ланглуа з посади директора Сінематеки, на його підтримку стали кінематографісти i насамперед режисери «нової хвилі».

Найкраще про події, які розгорнулися в ті часи, розповідає знов-таки Трюффо. Він зауважує, що, власне кажучи, протести на захист Ланглуа стали свого роду прелюдією до буремних подій травня 1968 року. Перші демонстрації, в яких спочатку брали участь лише «діти Сінематеки», відбулися у лютому 1968 року. Але дуже скоро, як свідчить Трюффо, з'явилися натовпи протестувальників, серед яких були і студенти, i маоїсти, i анархісти. Треба сказати, що під час демонстрацій «діти Сінематеки» не раз потрапляли під кийки поліції. Щоб урятувати фільмотеку, Ланглуа був ладен на все. 3 усмішкою згадує Трюффо, що директор навіть звертався до ворожок, щоб вони провістили йому майбутнє Сінематеки. Але підтримка Сінематеки та іiі директора і справді ви- 
явилась колосальною. Був створений «Комітет захисту Французької сінематеки», і боротьба велася не лише на вулиці. Статті на захист Ланглуа 3'явилися на шпальтах преси. Видатні кіномитці 3 усього світу брали участь у цій боротьбі. Це і Чаплін, і Куросава, і Сатьяджит Рей, і Росселліні. Це вони надіслали до часопису «Кайе дю Сінема» погрозу забрати свої фільми з Сінематеки, якщо iii не очолюватиме Ланглуа. Франсуа Трюффо завершує свої спогади фразою: «Як тільки Ланглуа було повернуто на свою посаду, до нас знову повернувся сон і ми відновили свої заняття» $[3,22]$. Ланглуа залишили на посту директора. Його зусиллями в 1973 році було відкрито Музей кіно.

Заради справедливості слід навести і аргументи противників Ланглуа, які ставили під сумнів його компетентність як хранителя Сінематеки. Справді, цей ентузіаст не завжди знав про найновітніші засоби зберігання кіноархівів, через що копії, які знаходились у сховищах Буа-д'Арсі, були зовсім не в кращому стані. Не викликали схвалення і методи фінансування тих чи інших галузей архівної роботи, які потрібно було принципово змінити. I все ж таки авторитет Ланглуа у світовому кінематографі залишався непохитним. В останні роки своєї роботи він зосередився максимально на створенні Музею кіно, який відкрився у 1972 році. В Музеї було представлено надзвичайно багато цікавих експонатів, від моделей декорацій, скажімо, фільму Мельєса — «Підкорення Північного полюсу», де в центрі поміщувалася смішна і жахлива постать північного велета, до кіночасописів різних країн і різних епох, серед яких був номер журналу «Сінемонд», в якому йшлося про прем'єру першого радянського кольорового фільму «Соловей-Соловушка, або Груня Корнакова» 3 Валентиною Івашовою в головній ролі. Французькі критики назвали цю актрису, яка знялася потім у численних українських фільмах радянським соловейком. Було представлено чимало постерів, афіш, серед яких і обличчя відомих кінокрасунь і всілякі чудовиська, зокрема, М. Шрек у ролі Носферату.

I, на завершення, слід наголосити ще раз, що пристрасне захоплення Ланглуа кіномистецтвом, його прагнення зберегти всі кінотвори, незалежно від того, в якій шкалі рейтингів вони стояли свого часу, дасть можливість глядачам інших історичних періодів дати цим творам власну оцінку.

1 «Sight \& Sound» - щомісячний британський журнал про кіно, який друкується 31932 року, а 3 1934 - під егідою Британського інституту кіно.
2 Пітер Гріневей (Peter Greenaway) - британський кінорежисер, письменник, сценарист і художник, поставив свою дебютну повнометражну стрічку «Контракт рисовальщика» завдяки фінансуванню Британського інституту кіно.

3 «Молоді розгнівані» (Angry уoung men) - термін, який виник завдяки автобіографічній книзі Л. А. Пола «Сердита молода людина» (1951р.) і об’єднав митців «покоління 50-х років» (або, як назвали їх пізніше, «дітей війни»). Найбільш визначними й типовими представниками «молодих розгніваних» вважаються романісти Кінгслі Еміс, Джон Вейн, Дж. Брейн, Дж. Осборн, Колін Вілсон та інші.

4 Луї Фейад (Louis Feuillade) - французький режисер, сценарист. Поставив серію з п’яти фільмів про Фантомаса (1913-1914), фільм «Вампіри» (1915), фільми «Жюдекс» і «Нова місія Жюдекса», кожен 3 яких складався більш як з десяти епізодів (1916-1917) та інш.

${ }^{5}$ Cep Альфред Джозеф Гічкок (Alfred Hitchcock) - англійський кінорежисер, продюсер, сценарист. Працював у Великій Британії та США. Його ім'я пов'язане зі становленням жанру «трилерів» (від англ. Thrill - «тремтіння» та 3 поняттям «саспенс» (від англ. Suspense - «невизначеність») у кіно. Поставив фільми «Запаморочення» (1958), «Психо» (1960), «Птахи» (1963) та інш.

6 Карл Теодор Дре́єр (Carl Theodor Dreyer) — данський кінорежисер-новатор, сценарист. Його фільм «Страсті Жанни д’Арк» (1927 р.) 1958 році був включено в число 12-ти найкращих фільмів усіх часів і народів за результатами анкетування Бельгійською сінематекою 117-ти істориків кіно і кінознавців 26-ти країн у зв'язку зі Всесвітньою виставкою у Брюсселі 1958 року.

${ }^{7}$ Рене Клер (René Clair, справжнє ім'я Рене-Люсь$\epsilon$ Шометт, фр. René-Lucien Chomette) - один з найзначиміших французьких кінорежисерів 1920-х і 1930х років, творець жанру музичного фільму, письменник, актор. Відстоював незалежність французького кінематографа від Голлівуду. Поставив такі фільми, як «Антракт» (1924), «Під дахами Парижа» (1930), «Примара їде на Захід» (1936).

8 Жан Кокто (Jean Cocteau) - французький письменник, поет, художник, кінорежисер. Одна 3 найзначніших постатей французької літератури XX століття.

9 Жан-Поль Шарль Емар Сартр (Jean-Paul Charles Aymard Sartre) - французький філософ, драматург, письменник. Сартр був одним із найвідоміших i найвпливовіших мислителів свого часу.

${ }^{10}$ Клод Шаброль (Claude Chabrol) - французький кінорежисер, сценарист, актор, продюсер. Шаброль $\epsilon$ одним з основоположників французької «нової хвилі», лідерами якої стали Жан-Люк Годар і Франсуа Трюффо. Поставив фільми «Кузени» (1959), (1991), «Криваве весілля» (1973), «Мадам Боварі», «У серці брехні» (1999) та інш.

11 Жан-Люк Годар (Jean-Luc Godard) - франко-швейцарський кінорежисер, актор, сценарист та продюсер; один 3 найвидатніших представників напряму «французької нової хвилі» у кінематографі, початком якої вважається його перший повнометражний фільм «На останньому подиху» (1960). 
12 Франсуа Трюффо (François Truffaut) - французький кінорежисер, сценарист, продюсер, один із засновників «нової хвилі». Спільно з Годаром писав статті до журналу свого кумира Андре Базена «Кінозаписник», згодом працював з Годаром над сценаріями фільмів «На останньому подиху» та «ІІторія води».

13 Жак Ріветт (Jacques Rivette) - французький кінорежисер та кінокритик, один із засновників течії «нова хвиля» у французькому кінематографі. Жак Ріветт один 3 небагатьох продовжував наслідувати принципи «нової хвилі», відстоюючи і роблячи авторське кіно. Серед фільмів, знятих Ріветтом, — «Черниця» (1966), «Божевільна любов» (1968), «Селін і Жюлі зовсім забрехалися» (1974) і 13-годинний «Не торкайся до мене» (1971).

14 Лотте Айснер (Lotte Henriette Eisner) - кінокритик, історик кіно, авторка фундаментальних монографій про Фріца Ланга та Фрідріха Мурнау, а також дослідження німецького кіноекспресіонізму «Демонічний екран» (1955).

15 Мюзідора - псевдонім французької актриси, танцівниці Жанни Рок, яка стала легендою французького кіно завдяки образу рокової жінки в серіалі «Вампіри» (1915). Пізніше Мюзідора допомагала Анрі Ланлуа у створенні Французької сінематеки.

\section{Джерела та література}

1. Ланглуа Ж. П., Майрент Г. // Жорж П. Ланглуа, Глен Майрент. Анри Ланглуа, первый гражданин кинематографа ; пер. с фр. // Искусство кино, 2001. № 5(травень). - С. 115-137.

2. Словарь французского кино ; [пер с фр. ; под ред. Ж. Л. Пассека]. — Минск : Пропилеи. — 1998. - 512 с.

3. Трюффо Ф. Трюффо о Трюффо ; пер. с фр. [вст. ст. К. Разлогова ; коммент. Н. Нусиновой] / Франсуа Трюффо. - М. : Радуга, 1987. — 456 с. 